\title{
PERAN FKDT DALAM PENGAWASAN PENDIDIKAN UNTUK MENINGKATKAN
} KUALITAS LEMBAGA

(Studi Deskriptif di Madrasah Diniyah Takmiliyah Uswatun Hasanah Tsani Kecamatan Kutawaringin)

\author{
Siti Nur Azizah1, Siti Asiah² \\ 1,2IKIP Siliwangi Bandung \\ 1sitinurazizah_20@yahoo.com
}

\begin{abstract}
ABSTRAK
Penelitian ini bertujuan untuk (1) mendapatkan informasi tentang peran FKDT dalam memotivasi MDT UHT, (2) mendapatkan informasi tentang peran FKDT dalam memfasilitasi MDT UHT, (3) mendapatkan informasi tentang peran FKDT dalam memngkoordinasi MDT UHT. Metode penelitian yang digunakan peneliti, menggukan metode deskriptif kualitatif. Adapun yang menjadi partisipan atau narasumber dalam penelitian ini ialah : Ketua Pengelola/Kepala Madrasah, dan 2 Guru di MDT UHT. Hasil penelitian ini menunjukkan tentang : (1) Peran FKDT dalam memotivasi lembaga MD UHTsani telah mampu memberikan motivasi dalam pembinaan kelembagaan, perencanaan, pelaksanaan, pengorganisasian, pengadministrasian, program kerja, dan pengajuan honor guru. Sebagai langkah-langkah dalam memotivasi lembaga dalam meningkatkan kualitas lembaga. (2) Peran FKDT dalam memfasilitasi lembaga MDT UHT lebih fokus dalam bidang pembelajaran yang meliputi metode pembelajaran, kurikulum, sarana prasarana, peserta didik dan tenaga pendidik. (3) Peran FKDT dalam mengkoordinir lembaga MDT UHT lebih fokus dalam bidang pelaoran kelembagaan.
\end{abstract}

Kata Kunci : FKDT, Kualitas Pendidikan, MDT

\section{A. PENDAHULUAN}

Tujuan pendidikan Islam (yang bersumberkan Al-Qur'an dan Hadist) adalah agar mencapai tujuan pembentukan aqidah yang kuat dan menanamkan dasar-dasar akhlaq melalui ajaran agama yang diturunkan untuk mendidik dan membimbing jiwa manusia serta menegakkan akhlaq yang baik untuk membangkitkan perkembangan dan pertumbuhan anak menjadi lebih baik (Efferi, 2011). Pendidikan diniyah adalah istilah lain dari sekolah agama, mulai diadakan di Indonesia berbarengan dengan penyebaran ajaran Islam di nusantara yang berbeda dengan keaadaan sekarang yang mengalami beberapa perubahan sesuai perkembangan zaman, setelah mengalami beberapa kali perubahan sesuai perkembangan zaman. ((DPP-FKDT), 2012).

Madrasah Diniyah (MADIN) merupakan lembaga pendidikan yang dikhususkan untuk siswa-siswi usia 7 sampai 18 tahun. Dimana pembelajaran yang diberikan secara klasikal berupa pengetahuan agama islam. Pendidikan dan pembelajaran (pada madrasah diniyah) bertujuan untuk memberikan tambahan wawasan agama di sekolahsekolah umum. (Saha, 2002). Namun pada kenyataanya lembaga madrasah diniyah masih dilihat rendah di masyarakat, dalam banyak hal tentunya sangat berbeda dengan sekolah formal, non formal, maupun lembaga-lembaga kursus umum lainnya. Namun 
sayangnya, kita kurang menyadari perbedaan tersebut, sering kali madrasah diniyah dianggap remeh oleh masyarakat. Namun sejak adanya peraturan daerah dan peraturan bupati bahwasanya setiap siswa yang akan meneruskan ke SMP wajib mengikuti ujian diniyah dan melampikan ijazah diniyah. Dikutip juga dalam koran pikiran rakyat bahwa "Sesuai dengan Perda dan Perbup kewajiban Diniyah Takmiliyah, maka setiap lulusan SD/MI harus mengantongi ijazah DTA". Oleh karena itulah perlunya pengawasan pendidikan agar masyarakat lebih paham akan pentingnya pendidikan MDT. Selain itu juga dengan adanya pengawasan pendidikan, diharapkan lembaga diniyah dapat meningkatkan kualitas lembaganya dan tertib dalam administrasi khususnya di lembaga MDT UHT.

Berbagai usaha dilakukan lembaga MDT UHT untuk mengoptimalkan dan memaksimalkan dalam proses administrasi lembaga dan proses pembelajaran diantaranya aktif di setiap kegiatan pertemuan FKDT Kecamatan Kutawaringin. FKDT seharusnya menjadi organisasi pendidikan agama islam yang secara terus menerus dalam mencerdaskan kehidupan bangsa yaitu sebagai upaya melengkapi materi pendidikan agama islam yang masih dirasa kurang pada sekolah umum. Kemudian masih adanya beberapa lembaga yang belum tertib dalam administrasi serta kelegalitasan lembaga, yang semestinya itu menjadi peran FKDT dalam pengawasan pendidikan dalam meningkatkan lembaga baik kegiatan belajar mengajar, administrasi dan kelegalitasan lembaga.

Merujuk pada latar belakang permasalahan yang ada, maka dalam penelitian ini penulis mencoba mendeskripsikan mengenai seberapa jauh FKDT dapat menjalankan tugasnya suatu organisasi profesi yang menghimpun unsur pendidik dan tenaga kependidikan madrasah diniyah, dan bagaimana perannya dalam membantu meningkatkan kualitas pendidikan di MDT UHT.

\section{B. KAJIAN TEORI}

1. Pendidikan Masyarakat (PENMAS)

Pendidikan masyarakat atau lebih popular disebut pendidikan non formal adalah usaha yang diharapkan dapat mempersiapkan dan mengembangkan sumber daya manusia agar mampu memiliki pengetahuan, keterampilan, sikap dan daya saing untuk memperoleh peluang yang berkembang dengan mengoptimalkan penggunaan sumbersumber yang ada dilingkungannya. Pendidikan nonformal dapat dikatakan sebagai pendidikan di luar pendidikan formal yang dilakukan di sekolah. Undang-undang No. 20 tahun 2003, disebutkan bahwa :

Pendidikan nonformal dapat didefinisikan sebagai jalur pendidikan di luar pendidikan formal yang dapat dilaksanakan secara terstruktur dan berjenjang. Dalam pengembangan pengembangan sumber daya manusia berkualitas dan berorientasi masa depan yang akan menjadi cikal utama pembangunan di berbagai sector, pendidikan luar sekolah dapat memegang peranan yang sangat strategis.

Pendidikan Masyarakat adalah salah satu system pendidikan nasional. Cangkupannya yang sangat luas dan kompleks menyebabkan pendidikan luar sekolah memerlukan batasan.

Selanjutnya dalam pasal 1 Peraturan Pemerintahan RI No. 73 tentang Pendidikan Masyarakat, dikemukakan bahwa "Pendidikan Masyarakat adalah pendidikan yang diselenggerakan di luar sekolah baik dilembagakan atau tidak". 
Pendidikan non formal ialah setiap kegiatan terorganisir dan sistematis, yang dilakukan diluar system persekolahan untuk melayani peserta didik dalam mencapai tujuan belajar. belajarnya.

Berdasarkan definisi diatas dapat disimpulkan bahwa pendidikan masyarakat dilakukan secara terrencana dan terprogram, untuk melayani peserta didik dalam mencapai tujuan pembelajaran.

\section{FKDT}

Organisasi ini lahir atas kesadaran dan kebulatan tekad masyarakat Indonesia untuk mendampingi, mengayomi, menjembatani, dan mengkomunikasikan penyelenggaraan dan kebijakan mengenai MDT, merupakan bagian dari pilar civil society berbasis pendidikan keagamaan Islam.

Dalam sejarah pendidikan Islam di Indonesia, MDT lahir sebelum Indonesia merdeka.. Kelahirannya ialah bagian dari metamorfosis, bahkan pada tingkat tertentu tidak bisa dilepaskan, dari lembaga pendidikan pondok pesantren, sehingga keberadaan antara pondok pesantren dengan MDT tidak bisa dipisahkan, karena penyelenggaraan MDT oleh dan berada di pesantren. Sebagian yang lain, MDT dilaksanakan di luar pondok pesantren terutama dengan memanfaatkan rumah ibadah seperti masjid, bahkan memiliki bangunan tersendiri.

Sementara sebagai institusi pendidikan, MDT memperkenalkan penyelenggaraan pendidikan berbasis masyarakat, merakyat, sederhana, dan penuh dedikasi keikhlasan. Hal inilah yang membuat MDT itu tetap eksis. Dengan posisi ini, MDT sungguh telah berkontribusi besar dalam merawat Islam-Indonesia yang santun, yang pada akhirnya menjadikan negara Indonesia sebagai negara yang mayoritas berpenduduk muslim. Oleh karenanya, kebijakan yang menafikan atau yang berpotensi mematikan MDT sesungguhnya menafikan Islam-Indonesia itu sendiri.

Kesadaran komunal masyarakat Indonesia atas eksistensi MDT cenderung mencapai puncaknya pasca lahirnya Peraturan Menteri Pendidikan dan Kebudayaan Nomor 23 Tahun 2017 tentang Hari Sekolah. Permendikbud ini dinilai oleh FKDT dan sebagian besar masyarakat muslim Indonesia berpotensi akan mematikan MDT sehingga terjadi aksi penolakan di berbagai provinsi di belahan nusantara ini. Namun, kegaduhan pasca munculnya Permendikbud 23/2017 ini cenderung mereda dengan kelahiran Peraturan Presiden Nomor 87 Tahun 2017 tentang Penguatan Pendidikan Karakter.

Di sisi lain, FKDT juga hendaknya patut direvitalisasi sebagai kekuatan civil society (masyarakat madani) yang memberikan input dan sekaligus penyeimbang atas kebijakan dan regulasi-kontraproduktif yang lahir dari negara. Pada titik tertentu, FKDT ada kalanya mendekat dengan negara bahkan menjadi ambil bagian dari kesuksesan kebijakan, dan pada titik yang lain FKDT harus berani menjauh dan memberikan kritikproduktif atas kebijakan yang diterapkan. Dengan memainkan peran ini, FKDT harus bersifat fleksibel namun konsisten dengan kebijakan yang pro-MDT.

Aspek lain yang mau tidak mau dilakukan oleh FKDT adalah harus menjadi gerbong dan kekuatan besar dalam menangani gelombang radikalisme-keagamaan yang terus terjadi di negeri ini. FKDT harus dapat menyadarkan masyarakat akan peran dan fungsi MDT, sebagai kekuatan terutama dalam membangun kesadaran keagamaan yang moderat dan berbasis keindonesiaan. MDT dan seluruh stakeholder pendidikan keagamaan 
Islam telah nyata menjadi bagian yang tidak terpisahkan dari kekuatan Islam-kultural yang mengajarkan kedamaian dan kebersamaan.

Untuk itu, secara akademik MDT harus mampu mengajarkan dan terus mempertahankan pengetahuan-pengetahuan keagamaan Islam yang berkarakter keindonesiaan. Ideologi keagamaan khas Indonesia menjadi kata kunci yang harus ditransformasikan dalam rangkaian akademik MDT. Demikian juga dengan kearifan lokal, semisal penguatan tulisan dan/atau bahasa pegon yang merupakan kekayaan khazanah keindonesiaan, perlu mendapat perhatian yang lebih serius.

Perluasan akses tidak untuk mendudukkan MDT sebagai bagian dari kegiatan ekstrakurikuler dari sekolah yang diposisikan sama seperi halnya lembaga kursus. Akan tetapi, kelembagaan MDT dihadirkan secara utuh dengan seperangkat kurikuler dan standar ketenagaan yang mumpuni, dengan memanfaatkan bangunan sekolah.

Tentu, di samping beberapa usulan di atas masih banyak usulan dan strategi yang ada baiknya didiskusikan secara serius oleh peserta Rapat Kerja Nasional. Kehadiran dan diskusi peserta dan pengurus yang baru diharapkan melahirkan ide-ide kontributif bagi pengembangan MDT dan pendidikan keagamaan Islam lainnya. Seluruh masyarakat Indonesia berharap kiranya FKDT dapat melahirkan ide dan program kerja yang mampu benar-benar memperkuat keagamaan dan keindonesiaan sekaligus.

\section{Peran FKDT}

Adapun Peran FKDT adalah Sebagai Motivator, Fasilitator Dan Koordinator :

a. Motivator; FKDT diharapkan mampu berperan dan menjadi pendorong terhadap lembaga madrasah diniyah untuk mewujudkan cita-citanya, (menjadikan peserta didik berakhlak mulia, memiliki aqidah yang kuat dan dapat melaksanakan ibadah dengan baik dan benar) seperti;

1) Menyelenggarakan pelatihan atau seminar mengenai kediniyahan.

2) Menjadikan lembaga madrasah diniyah yang aktif, kreatif dan inovatif.

b. Fasilitator; FKDT diharapkan dapat berperan sebagai jembatan atau penghubung dengan peraturan yang di tetapkan oleh pemerintah. Serta dapat menjadi sumber peningkatan mutu SDM, program pembelajaran, pembiayaan serta fasilitas sarana dan prasarana diniyah.

c. Koordinator;

1) FKDT harus menjadi penggerak dan pemandu diniyah takmiliyah menjadi kearah yang lebih maju, kridibel dan akuntabel.

2) FKDT yang berada diluar tatanan birokrasi harus dapat bergerak secara dinamis dan luwes.

3) FKDT harus mampu menjadi pemimpin dalam memanage maupun mengkoordinasikan anggota, ia harus berani berpikir dan bertindak out box tidak boleh terkungkung dalam in box berani keluar dari "satus quo" bila dianggap lebih baik.

4. Visi Dan Misi

Visi : Terwujudnya Forum Komunikasi Kerja Diniyah Takmiliyah Sebagai Mitra Kerja Kementrian Agama Yang Handal Dan Inovatif.

Misi :

a. Memperkuat Keberadaan Lembaka Forum Komunikasi Diniyah Takmiliyah. 
b. Mempererat Persatuan Dan Kesatuan Diniyah Takmiliyah.

c. Mempererat kerjasama yang baik dengan Departemen Agama.

d. Memperkuat kerjasama anatara lembaga dan pemerintah daerah.

5. Pendidikan Madrasah Diniyah Takmiliyah

Jika dikaji dari pengertian bahasa, istilah madrasah merupakan isim makan (nama tempat), berasal dar kata darasa, yang bermakna tempat orang belajar. Dari dasar makna tersebut sering pula disebut tempat mendidikan, khususnya mengenai pendidikan islam.

Madrasah diniyah adalah tempat dimana pembelajaran yang diberikan hanya tentang keagamaan islam. Madrasah ini ditujukan bagi siswa di sekolah umum untuk memperoleh pendidikan agama islam.

Jenjang pendidikan pada Madrasah Diniyah tersusun sebagai berikut:

a) Madrasah Diniyah Awaliyah diperuntukan bagi siswa sekolah dasar (4 tahun)

b) Madrasah Diniyah Wustha diperuntukan bagi siswa sekolah lanjutan pertama (3 tahun)

c) Madrasah Diniyah Aliyah / 'Ulya diperuntukan bagi siswa sekolah lanjutan atas (3 tahun)

6. Manajemen Organisasi FKDT

Manajemen mengandung arti semua kegiatan yang diselenggarakan oleh seseorang atau lebih, dalam suatu kelompok atau organisasi/lembaga, untuk mencapai tujuan yang telah ditetapkan dalam organisasi/lembaga.

Pendidikan adalah usaha sadar untuk menyiapkan peserta didik melalui kegiatan bimbingan, pengajaran atau pembelajaran dan/atau pelatihan bagi peranannya di masa yang akan datang.

Undang-undang Nomor 20 Tahun 2003 Tentang Sistem Pendidikan Nasional, system pendidikan nasional mencakup tiga jalur (sub sistem) yaitu pendidikan formal, pendidikan nonformal, dan pendidikan informal. Adpaun pendidikan nonformal adalah setiap usaha yang dilakukan dengan sadar, sengaja, teratur, dan berencana yang bertujuan untuk membantu peserta didik dalam mengembangkan dirinya sehingga terwujud manusia yang gemar belajar-membelajarka, mampu meningkatkan taraf hidup, dan berpartisipasi dalam kegiatan sosial atau pembangunan masyarakat.

Terry tahun 1987 (Imam Gunawan, 2017) mengemukakan empat proses manajemen, yang dapat disingkat dengan POAC, yaitu:

a. Planning (perencanaan) adalah proses kegiatan rasional dan sitematik dalam menetapkan keputusan, kegiatan atau langkah-langkah yang akan dilaksanakan dikemudian hari dalam rangka usaha mencapai tujuan secara efektif dan efisien".

b. Organizing (pengorganisasian) adalah menyusun hubungan perilaku yang efektif antar personal, sehingga mereka dapat bekerjasama dalam melaksanakan tugastugasnya secara efesien guna mencapai tujuan dan sasaran tertentu.

c. Actuating (penggerakan) adalah proses mengarahkan dan mempengaruhi aktifitas yang berkaitan dengan pekerjaan dari anggota kelompok atau seluruh orgainasasi. 
d. Controlling (pengawasan) adalah proses pemantauan, pelaporan, penilaian, dan perencanaan atas pencapaian yang telah ditetapkan untuk tindakan koreksi guna penyempurnaan lebih lanjut.

Adapun salah satu tugas Forum Komunikasi Diniyah Takmiliyah (FKDT) adalah sebagai Controlling (pengawasan). Bahwa ketuntasan belajar tergantung pada banyak hal terutama pada pokok pembahasan yang diajarkan dikelas. Diantaranya tergantung pada kemampuan guru dalam menyampaiakan materi, potensi peserta didik, metode pembelajaran yang diberikan dan system pengaturan proses belajar mengajar seperti alokasi waktu yang tersedia, system ulangan/evaluasi.

\section{METODE}

Dalam penelitian ini, peneliti menggunakan metode kualitatif. Dengan harapan peneliti dapat mengungkapkan dan memahami fakta-fakta atau gambaran sesuai dengan kenyataan dilapangan tanpa melakukan intervensi terhadap kondisi yang terjadi. Penelitian yang digunakanpun melalui studi deskriptif. Penelitian ini mengambil lokasi di MDT Uswatun Hasanah Tsani Kp. Sukawangi Rt. 02/05 Desa Jelegong Kecamtan Kutawaringin Kabupaten Bandung. Dalam peneletian ini diambil 3 partisipan, yaitu 1 Kepala Madrasah dan 2 orang guru MDT Uswatun Hasanah Tsani. Untuk dapat memperoleh data yang diperlukan, agar sesuai dengan tujuan penelitian. Maka penulis menggunakan teknik pengumpulan data dengan cara observasi, wawancara, dan dokumentasi.

\section{HASIL DAN PEMBAHASAN}

\section{Sejarah Berdirinya MDT UHT}

Sejarah Islam di Indonesia memperlihatkan bahwa pendidikan keagamaan di sini tumbuh dan berkembang seiring dengan perkembangan kehidupan masyarakat muslim. Seiring perkembangan zaman pendidikan agama islam terus berkembang dari awal mula dilakukan secara tradisional, berupa pengajian Al_qur'an dan hadist, serta pengajian kitab kuning yang di kenalkan (terutama di Jawa) dengan nama sorogan, talaran. Tempat belajar yang digunakan biasanya surau atau lebih dikenal madrasah, tempat "umum" orang melaksanakan ibadah shalat, meskipun sulit untuk menelaah kapan awal mula berdirinya atau lahirnya madrasah diniyah. Tetapi Departemen Agama telah mengakui bahwa setelah Indonesia merdeka sebagian besar sekolah agama berstatus sebagai pendidikan keagamaan luar sekolah.

Madrasah Diniyah Takmiliyah Uswatun Hasanah Tsani adalah salah satu lembga pendidikan agama islam yang berada di wilayah Kecamatan Kutawaringin Kabupaten Bandung berawal dari lembaga non formal. Suatu lembaga pendidikan non formal didirikan pada tahun 2011 oleh sekelompok masyarakat tokoh masyarakat maupun tokoh agama Islam yang memiliki kepedulian terhadap pendidikan Islam yang dipelopori oleh Bapak Komarudin Shaleh sebagai Pembina Yaysan Uswatun Hasanah Jelegong. Dan dilanjutkan oleh putra ketiganya yang bernama Dik Dik Rizqi Fauzi yaitu selaku ketua yayasan dan merangkap sebagai kepala madrasah diniyah takmiliyah uswatun hasanah tsani.

Sebagai lembaga non formal "Madrasah Diniyah Takmiliyah" tentunya madrasah ini semakin tahun mengalami banyak perubahan dan kemajuan. Seiringa dengan kemajuan tersebut pada tahun 2011, dengan segala upaya dibawah naungan organisasi Forum Komunikasi Diniyah Takmiliyah (FKDT) kecamatan kutawaringin mencoba untuk lebih 
menjadikan "Madrasah Diniyah Takmiliyah" dalam bentuk pendidikan yang pada nantinya madrasah ini dapat berjalan proses belajar mengajarnya, melaksanakan ujian negara seperti halnya yang dilakukan pada sekolah formal pada umumnya.

Perkembangan MDT Uswatun Hasanah Tsani sangat pesat, sebagai salah satu lembaga pendidikan non formal yang pertama berdiri di wilayah Kp. Sukwangi RT. 02 Rw. 05 Desa Jelegong Kecamatan Kutawaringin Kabupaten Bandung. Telah dipandang mampu menjalankan proses belajar mengajar dengan baik.

Berdasarkan Surat Keputusan Kepala Kantor Departemen Agama Kabupaten Bandung No. SK : Kd.10.4/5/PP.00.8/1085/2011 tanggal 28 Januari 2011, Diniyah Takmiliyah Uswatun Hasanah Tsani terdaftar secara resmi di Kantor Departemen Agama Kabupaten Bandung dengan Nomor Statistik Diniyah Takmiliyah (NSDT) : 311.2.32.04.2303. Telah ditetapkan pada tanggal 28 Januari 2011.

Diniyah Takmiliyah Uswatun Hasanah Tsani sejak awal berdiri hingga sekarang terus mengalami perkembangan, baik dari segi fisik bangunan maupun dari kurikulum pembelajaran yang terus berkembang di bawah organisasi Forum Komunikasi Diniyah Takmiliyah (FKDT) Kecamatan Kutawaringin yang salah satu tugasnya mengawasi lembaga-lembaga diniyah di daerah kecamatan kutawaringin.

Adapun Visi, Misi dan Tujuan dari lembaga MDT Uswatun Hasanah Tsani adalah sebagai berikut:

a. Visi

1. Menjadikan peserta didik berakhlakul karimah sesuai syariat agama islam.

b. Misi

1. Melaksanakan pembelajaran yang berpusat pada peserta didik.

2. Memberikan kegiatan pembelajaran praktik ibadah untuk diaplikasikan dalam kehidupan sehari-hari.

3. Melaksanakan kerja sama dengan pihak lain seperti orang tua, lembaga pengasuhan lain agar pendidikan anak maksimal.

c. Tujuan

1. Menjadikan peserta didik agar mampu membaca Al-Qur'an dengan baik dan benar;

2. Dapat menjalankan sholat lima waktu dengan baik dan benar;

3. Anak mampu menghafal juz amma dan mampu memahami beberapa kutipan AlQur'an yang relevan dengan kurikulum;

4. Menghafal do'a-do'a harian serta dapat mengimplementasikan dalam kehidupan sehari-hari;

5. Anak bisa mengerti dan memahami nilai-nilai dasar agama Islam secara sederhana meliputi Aqidah Akhlak, Fiqih Ibadah dan dapat mengimplementasikan dalam kehidupan sehari-hari.

\section{Penyelenggaraan MDT Uswatun Hasanah Tsani}

a. Pelaksanaan Pembelajaran

MDT Uswatun Hasanah Tsani Kecamatan Kutawaringin terdiri dari dua tingkatan. Yaitu Diniyah dan Wusto. Diniyah dan Wusto dilaksanakan pada hari yang sama hanya saja jam pembelajaran yang berbeda. Adpun jadwal pembelajaran yang dilaksanakan dimulai dari hari senin sampai dengan sabtu. 
Untuk Diniyah dilaksanakan 2 (dua) semester setara SD formal. Untuk kelas I (satu) dimulai dari pukul 13:00 - 14:00 dan selanjutnya diteruskan oleh kelas II (dua), dan terus menerus sampai dengan kelas VI (enam) berangsur satu jam-satu jam. Untuk Diniyah metode pembelajaran menggunakan Kurikulum DTA 2010 yang di dalamnya berisi pembelajaran Al-Qur'an, Al-Hadits, Aqidah, Akhlah, Fiqih, Tarikh Islam (SKI), Bahasa Arab. Adapun tambahan pembelajaran atau muatan lokal yaitu disesuaikan dengan kelas peseta didik. Seperti di kelas 1 (satu) dan II (dua) Diniyah muatan lokal yang diberikan yaitu hafalan surat-surat pendek, dan do'a-do'a pendek. Sedangkan dari kelas III (tiga) samapai dengan VI (enam) yaitu hafalan ilmu tajwid kemudian diaplikasikan pada pembacaan ayat suci Al-Qur'an, doa wudhu beserta praktinya, hafalan bacaan sholat wajib 5 (lima) waktu, sholat jenazah, sholat sunah lainnya dan diserta praktinya, serta do'a dan sholawat yang senantiasa dilaksanakan dalam kehidupan sehri-hari.

Sedangkan untuk tingkatkan Wusto setara SMP pembelajaran dilaksanakan stelah sholat magrib berjama'ah sekitar pukul 18:15 WIB. Materi yang diberikan adalah kajian kitab kuning, tajwid, dan tafsir qur'an. Untuk jenjang wusto tentunya pembelajaran lebih luas untuk bekal peserta didik dalam hidup bermasyarakat.

b. Kurikulum Pembelajaran

Berdasarkan Undang-undang Pendidikan dna Peraturan pemerintah no 73 tahun 1991 pada pasal 1 ayat 1 disebutkan "Penyelenggaraan pendidikan diluar sekolah boleh dilembagakan dan boleh tidak dilembagakan". Dengan jenis "pendidikan Umum" (psl 3. ayat.1). sedangkan kurikulum dapat tertulis dan tertulis (pasl. 12 ayat 2). Bahwa Madrasah Diniyah adalah bagian terpadu dari system pendidikan nasional yang diselenggarakan pada jalur pendidikan luar sekolah untuk memenuhi hasrat masyarakat tentang pendidikan agama.

Dalam program pengajaran ada bebarapa bidang studi yang diajarkan seperti Qur'an Hadits, Aqidah Akhlak, Fiqih, Sejarah Kebudayaan Islam, Bahasa Arab, dan Praktek Ibadah.

Kurikulum Madrasah Diniyah pada dasarnya bersifat fleksibel dan akomodatif. Oleh karena itu, pengembangannya dapat dilakukan oleh Departemen Agama Pusat Kantor Wilayat/Depag Propinsi dan Kantor Departemen Agama Kabupaten/Kotamadya atau oleh pengelola kegiatan pendidikan sendiri. Prinsip pokok untuk mengembangkan tersebut ialah tidak menyalahi aturan perundang-undangan yang berlaku tentang pendidikan secara umum, peraturan pemerintah, keputusan Menteri Agama dan kebijakan lainnya yang berkaitan dengan penyelenggaraan madrasah diniyah. Khususnya bagi Kecamatan Kutawaringin Kabupaten Bandung Kurikulum yang dugunakan adalah Kurikulum DTA 2010.

c. Metode Pembelajaran

Pembelajaran disampaikan secara klasikal dan Individual. Adapun metode yang sering digunakan adalah ceramah, unjuk kerja, dan hafalan serta metode lain yang sifatnya insidentil.

\section{d. Evaluasi}

Evaluasi yang diberikan kepada peserta didik berupa ulangan harian, ujian akhir semester dan ujian akhir madrasah. Dalam pelaksanaan ulangan harian dilakukan pada setiap akhir bab pembelajaran. Untuk pelaksanaan ulangan harian sepenuhnya 
diberikan kewengan kepada tenaga pendidik/guru mata pelajaran. Sedangkan untuk ujian akhir semester dan ujian akhir madrasah di tentukan oleh departemen agama yang dapat diakses melalui kalender pendidikan. Dengan pemberian soal ujian yang dikelola oleh FKDT Kecamatan Kutawaringin Kabupaten Bandung.

\section{e. Manajemen Keuangan}

Sebagaimana telah dijelaskan terdahulu, bahwa untuk mendukung operasional Madrasah setiap santri dipungut biaya sebesar Rp. 15000,-/bulan, walaupun dalam kenyataanya masih ada santri yang belum aktif dalam pembayaran uang syahriyyah tersebut. Uang tersebut dikelola secara mandiri, dan sepenuhnya dialokasikan untuk biaya operasional Madrasah.

Adapun untuk kegiatan peringatan hari besar Islam dan Pentas kreasi seni santri pada akhir tahun ajaran, pihak madrasah bekerja sama dengan orang tua santri untuk memenuhi kebutuhan dana tersebut.

\section{f. Tata Tertib}

Untuk mendukung kelancaran pelaksanaan program belajar mengajar di Diniyah Takmiliyah Uswatun Hasanah Tsani, yang meliputi :

1) Lima menit sebelum pembelajaran santri sudah hadir di madrasah.

2) Berprilaku sopan dan santun baik terhadap guru maupun teman, dilingkungan madrasah ataupun di luar madrasah.

3) Berpakaian sopan dan Islami selama proses pembelajaran.

4) Apabila berhalangan hadir maka santri wajib memberikan surat keterangan dari orangtua.

5) Disiplin dan bersungguh-sungguh dalam mengikuti pembelajaran.

6) Wajib melaksanakan shalat wajib di waktu, ashar, magrib dan isya sesuai jam kelas masing-masing.

\section{g. Sarana dan Prasarana}

Sarana dan prasarana yang beralokasi di MDT Uswatun Hasanah Tsani ini memiliki luas tanah dan bangunan $210 \mathrm{~m}^{2}$. Dengan memiliki beberapa ruangan, diantaranya : ruang kelas I-VI secara bergantian, toilet, dapur, kamar pondok (bagi santri yang menginap).

Pada awalnya pembelajaran dilaksanakan di rumah ustadz dicky sebelum madrasah memiliki bangunan tersendiri. Hingga akhirnya pada tahun 2011 ayah dari ustadz dicky yaitu bapak Komarsa membeli tanah dan membangun sebuah madrsah yang hingga saat ini dijadikan tempat kegiatan belajar mengajar.

Adapun sarana prasarana belum begitu lengkap, parasantri dalam proses kegiatan belajar mengajar masih menggunakan leher (meja panjang) yang dapat digunakan bersama-sama, belum adanya meja dan kursi bagi parasantri. Adapun sarana prasarana yang lainnya adalah : papantulis (whiteboard) berjumlah 2 (dua), spidol dan penghapus, meja dan kursi guru 1 (satu), alat kebersihan (tong sampah, sapu dan lap pel), bukubuku penunjang pembelajaran dan tentunya tersedianya Al-Qu'an dan Iqra diperuntukan bagi para santri yang tidak membawa dari rumah masing-masing.

\section{Pembahasan}

Peran FKDT adalah sebagai motivator, fasilitator, dan coordinator ketiga tahapan tersebut adalah harapan bagi lembaga agar dapat terlaksanakan 
Berikut adalah langkah-langkah peran FKDT dalam memotivasi, memfasilitasi dan mengkoordinasi di lembaga MDT Uswatun Hasanah Tsani.

a. Langkah-langkah FKDT dalam Memotivasi lembaga MDT Uswatun Hasanah Tsani Hasil penelitian ini diperoleh dari observasi, wawancara dan dokumentasi. Wawancara yang dilakukan oleh peneliti yaitu dengan kepala madrasah tentang peran FKDT dalam meningkatkan kualitas lembaga, terutama langkah-langkah FKDT dalam memotivasi lembaga MDT Uswatun Hasanah Tsani.

Tentunya dalam meningkatkan kualitas lembaga MDT Uswatun Hasanah Tsani tidak terlepas dari motivasi yang dilakukan oleh FKDT Kecamatan Kutawaringin. Dari mulai perencanaan pembelajaran tahunan, semesteran hingga pembelajaran harian. Semua itu tidak terlepas dari kurikulum DTA tahun 2010 yang selalu disosialisasikan oleh Ketua FKDT. Peranan FKDT sebagaimana menurut Menurut Biddle dan Thomas dalam Arisandi, peran adalah serangkaian rumusan yang membatasi perilaku-perilaku yang diharapkan dari pemegang kedudukan tertentu. Misalnya dalam keluarga, perilaku ibu dalam keluarga diharapkan bisa memberi anjuran, memberi penilaian, memberi sangsi dan lain-lain. Hal serupa juga yang diharapkan setiap lembaga. Bahwasanya FKDT dapat memberi masukan, penilaian, untuk meningkatkan kualitas lembaga, dan sangsi bagi setiap lembaga tidak taat aturan.

Tidak hanya itu saja, FKDT Kecamatan Kutawaringin diharapkan dapat melaksanan peranannya sebagai Motivator yang dapat mendorong setiap lembaga Madrasah Diniyah agar mampu mewujudkan cita-citanya.

Langkah-langkah Motivasi yang dilakukan FKDT terhadap MDT Uswatun Hasanah Tsani adalah sebagai berikut :

1) Membina dalam pengurusan perijinan lembaga MDT.

2) Memberikan arahan tentang perencanaan pembelajaran.

3) Memberikan masukan tentang pelaksanaan kegiatan pembelajaran.

4) Memberikan pemahaman tentang administrasi lembaga.

5) Mengikutsertakan dalam keaktifan organisasi FKDT.

6) Membenahi administrasi lembaga.

7) Menindaklanjuti program kerja yang telah dibuat oleh lembaga.

8) Mengajukan honor guru perbulan.

Maka dapat ditarik kesimpulan bahwa FKDT Kutawaringin telah mampu melaksanakan sebagaimana perannya, yakni sebgai motivator bagi lembaga yang memiliki kemauan untuk meningkatkan kualitas lembaganya.

b. Langkah-langkah FKDT dalam Memfasilitasi lembaga MDT Uswatun Hasanah Tsani Selain memberikan memotivasi kepada lembag, FKDT juga berperan sebagai Fasilator yang menjadi jembatan atau penghubung anatara tuntutan dan kebutuhan Madrasah Diniyah dengan pemerintah dan masyarakat atau sebaliknya dari kebuntuan dan keterbatasan peningkatan mutu SDM, Program, Pembiayaan serta fasilitas sara dan prasarana Diniyah. 
Adapun langkah-langkah FKDT Kutawaringin dalm memfasilitasi lembaga MDT Uswatun Hasanah Tsani adalah sebagai berikut :

1) Memberikan metode pembelajaran yang harus diterapkan di lembaga.

2) Menyediakan buku pembelajaran sesuai kurikulum DTA 2010.

3) Menyediakan buku raport peserta didik

maka dapat ditarik kesimpulan bahwa FKDT Kutawaringin telah mampu melaksanakan perannya sebagai fasilitator, meski masih terdapat kekurangnya dibidang sarana prasarana yang belum dapat difasilitasi oleh FKDT. Namun lembaga selalu berharap jika kelak FKDT dapat mengusakan atau mengajukan bantuan sarana dan prasarana bagi lembaga MDT.

c. Langkah-langkah FKDT dalam Mngkoordinasi lembaga MDT Uswatun Hasanah Tsani

Selain pera FKDT sebagai motivator, fasilitasor dan yang terakhir adalah Koordinator. Adapun yang dimaksud koordinator adalah FKDT diharapkan dapat mengkoordinir semua lembaga Madrasah Diniyah Takmiliyah kearah yang lebih maju, kreadibel dan akuntabel.

Adapun langkah-langkah yang dilakukan oleh FKDT Kecamatan Kutawaringin dalam mengkoordinir lembaga di MDT USwatun Hasanah Tsani adalah sebagai berikut :

1) Selalu diadakannya laporan berkala kesiswaan dalam bentuk Education Management Information System (EMIS) yang merupakan sistem informasi yang dikembangkan oleh kementerian agama untuk memudahkan input data sekolah, pondok pesantren dan pendidikan tinggi Islam.

2) Serta diadakannya pengkoordinaran rutin dalam pelaksanaan Ujian Nasional (UN) dan Ujian Akhir Semester (UAS) baik dalam pelaksanaan maupun dalam penilaian soal. Ini dilakukan agar tidak terjadi kecurangan baik pada lembaga ataupun pada peserta didik. Agar semuanya transparan dengan hasil yang maksimal serta kejujuran.

3) Dalam upaya peningkatan kualitas lembaga, FKDT juga melakukan pengecekan Laporan Penanggung Jawaban (LPJ) bagi guru Diniyah yang telah menerima honor perenam bulan sekali. Ini semua dilakukan untuk kemajuan semua lembaga.

Hasil Pembinaaan dari Program Pengawasan Pendidikan yang dilakukan FKDT

Setalah dilaksanakan pengawasan pendidikan oleh FKDT Kec. Kutawaringin bahwa MDT UHT adalah salah satu lembaga yang mampu melaksanakan semua program yang telah ditetapkan oleh FKDT Kec. Kutawaringin, dan sudah berlegalitas serta dapat melaksanakan pembelajaran kurikulum DTA 2010 dengan baik, serta berhak menerima tunjangan honor guru dari anggaran APBD Kabupaten atas kerja keras dan kerjasama yang baik dalam memajukan dunia pendidikan islam.

\section{E. KESIMPULAN}

Dari hasil penelitian yang didapat melaui observasi, wawancar, dan dokumentasi mengenai "Peran FKDT Dalam Pengawasan Pendidikan Untuk Meningkatkan Kualitas Lembaga". Maka di bab akhir ini disampaikan kesimpulan dan saran. 
1. Peran FKDT dalam meningkatkan kualitas pendidikan di lembaga MDT UHT sebagi motivator, fasilitator, dan koordinator telah berjalan dengan baik. Serta dapat dilaksanakn oleh lembaga MDT UHT.

2. Peran FKDT dalam memotivasi lembaga MDT UHT telah mampu memberikan motivasi dalam pembinaan kelembagaan, perencanaan, pelaksanaan, pengorganisasian, pengadministrasian, program kerja, dan pengajuan honor guru. Sebagai langkah-langkah dalam memotivasi lembaga untuk meningkatkan kualitas lembaga.

3. Peran FKDT dalam memfasilitasi lembaga MDT UHT lebih fokus dalam bidang pembelajaran yang meliputi metode pembelajaran, kurikulum, sarana prasarana, peserta didik dan tenaga pendidik.

4. Peran FKDT dalam mengkoordinir lembaga MDT UHT lebih fokus dalam bidang pelaoran (Langgulung, 2003).

\section{F. DAFTAR PUSTAKA}

Hasil Musyawarah Nasional Munas I Dewan Pengurus Pusat Forum Komunikasi Diniyah Takmiliyah (DPP-FKDT), (2012). Lebak Bulus Cilandak Jakarta Selatan.

H.M.Arifin, (2003). Ilmu Pendidikan Islam. Jakarta: Bumi Aksara.

Adri Efferi, (2011). Filsafat Pendidikan Islam. Jawa Tengah: STAIN Kudus.

George, T. R. (2006). Asas-Asas Manajemen. Bandung : PT. Bumi Aksara.

Fuad Ihsan, (1997). Dasar-Dasar Kependikan. Jakarta: PT Rineka Cipta.

Imam Gunawan dan Djum djum Noor Benty (2017: 29) Gunawan, I., dan Benty, D. N. (2017). Manajemen Pendidikan. Bandung: Alfabeta.

Langgulung, H. (2003). Asas-Asas Pendidikan Islam. Jakarta: PT. Pustaka Al-Husna Baru

S. Djurarsa Sendjaya, d. (2009). Pengantar Ilmu Komunikasi. Jakarta: Universitas Terbuka.

M. Ishom El Saha, (2002). Dinamika Madrasah Diniyah Di Indonesia. Bogor: Pustaka Mutiara.

Syarifudin, H. E. (2001). Manajemen Pendidikan. Jakarta: Diadit Media. 